\title{
Surgical site infection and its risk factors in colon surgeries
}

\author{
Infecção de sítio cirúrgico e seus fatores de risco em cirurgias de cólon \\ Infección de sitio quirúrgico y sus factores de riesgo en cirugías de colon
}

Suzimar de Fátima Benato Fusco ${ }^{1}$, Natiara Medolago Massarico², Maria Virginia Martins Faria Fadul Alves ${ }^{3}$, Carlos Magno Castelo Branco Fortaleza ${ }^{4}$, Érika Cibele Pereira Pavan², Valéria de Castilho Palhares ${ }^{3}$, Carlos Eduardo de Melo², Marla Andréia Garcia de Avila $^{3}$, Maria José Trevizani Nitsche ${ }^{3}$

How to cite this article:

Fusco SFB, Massarico NM, Alves MVMFF, Fortaleza CMCB, Pavan ECP, Palhares VC, et al. Surgical site infection and its risk factors in colon surgeries. Rev Esc Enferm USP. 2016;50(1):43-9. DOI: http://dx.doi.org/10.1590/S0080-623420160000100006

${ }^{1}$ Universidade Estadual Paulista "Júlio de Mesquita Filho", Faculdade de Medicina, Programa de Pós-Graduação em Enfermagem, Botucatu, SP, Brazil.

${ }^{2}$ Universidade Estadual Paulista "Júlio de Mesquita Filho”, Hospital das Clínicas, Botucatu, SP, Brazil.

${ }^{3}$ Universidade Estadual Paulista "Júlio de Mesquita Filho", Faculdade de Medicina, Departamento de Enfermagem, Botucatu, SP, Brazil.

${ }^{4}$ Universidade Estadual Paulista "Júlio de Mesquita Filho”, Faculdade de Medicina, Departamento de Doenças Tropicais e

Diagnóstico por Imagem, Botucatu, SP, Brazil.

\begin{abstract}
Objective: To identify the occurrence of surgical site infection (SSI) and its risk factors in patients undergoing colon surgery in a tertiary hospital located in the countryside of the state of São Paulo. Method: Retrospective cohort study, with collection of information contained in the medical records of patients undergoing colon surgery in the period between January 2010 and December 2013. The studied variables were the possible risk factors related to the patient, to demographic characteristics and the surgical procedure. Results: In total, were evaluated 155 patients with an overall SSI incidence of $16.7 \%$. A statistically significant association was found both in the univariate as in the multivariate analysis between the SSI and the following variables: male gender, Charlson index and mechanical bowel preparation. Conclusion: The understanding of health professionals about the factors that influence the incidence of SSI in colon surgery may contribute to the quality of care provided to surgical patients, from effective actions to minimize the risk of infections.
\end{abstract}

\section{DESCRIPTORS}

Surgical Wound Infection; Colorectal Surgery; Perioperative Nursing.
Corresponding author:

Suzimar de Fátima Benato Fusco

Av. Prof. Montenegro, s/n. Anexo Vermelho

Distrito de Rubião Junior

CEP 18618-970 - Botucatu, SP, Brazil

sbenato@fmb.unesp.br
Received: 07/16/2015

Approved: 10/07/2015 


\section{INTRODUCTION}

The surgical site infection (SSI) has been pointed as the type of highest prevalence among infections associated with avoidable health care ${ }^{(1)}$. It is also the second or third most common infection in the world among patients undergoing surgeries ${ }^{(2)}$.

In Brazil, SSI ranks third among infections found in health services and represents $14-16 \%$ of infections in hospitalized patients ${ }^{(3)}$. The diagnosis of SSI is done by observing several factors, namely: the emergence of infection must occur within 30 days after surgery, or in cases of prosthesis implantation, in up to a year ${ }^{(2-3)}$.

An extensive surveillance program can reduce the rates of surgical site infections in 30 to $40 \%$, and for its effectiveness, the real incidence of these infections and associated risk factors must be known ${ }^{(4)}$.

In the literature, the SSI rates in colon surgery varied from 3.5 to $21.3 \%$, and are pointed as the largest SSI rates among elective procedures ${ }^{(5-11)}$. But diagnosing SSI only during hospital stay has not provided actual rates, which may underestimate the real values, as shown in a national study that notified $75 \%$ of SSI during post-discharge surveillance ${ }^{(10)}$.

In the literature, the most prevalent risk factors for SSI in colon surgery related to the patient were: age $>75$ years, obesity and classification of the American Society of Anesthesiology $(\mathrm{ASA}) \geq 3$. For the factors related to the surgical procedure, the most prevalent were: long surgeries (time > $240 \mathrm{~min}$ ), surgery classification according to the potential for contamination and open surgical approach ${ }^{(5-10)}$.

Given the importance of measures for the prevention and control of SSI because of its high rates in colon surgery and the possibility of applying evidence-based interventions on risk factors associated with SSI, this study aimed to verify the incidence of SSI and its risk factors related to the patient and the surgical procedure in patients undergoing colon surgery in a tertiary hospital in the countryside of São Paulo.

\section{METHOD}

This is a retrospective cohort study. It was conducted at the Hospital das Clínicas of the Faculdade de Medicina de Botucatu (HC-FMB), located in the countryside of the state of São Paulo.

The study included adult patients (age $\geq 18$ years) undergoing colon surgery between January 2010 and December 2013, in follow-up from admission until discharge, and who received calls from a staff member the Committee of Infection Control related to Health Care (CCIRAS) of the HC-FMB 30 days after the date of surgery. The contact after patients' discharge was done by nurses of the CCIRAS of the HC-FMB. Patients whose medical records were not available for consultation during the study period were excluded.

The epidemiological surveillance of hospital infections is part of the usual work routine of the CCIRAS nurses. The recommendations of the National Health Surveillance Agency (ANVISA) are used as diagnostic criteria for the SSI diagnosis ${ }^{(3)}$.
The information of patients' medical records and the epidemiological surveillance form completed by the CCIRAS nurses were used for data collection. The information of all hospital-acquired infections of the HC-FMB was also taken from these sources. All data were transcribed into a predetermined form.

The studied variables were:

Demographic: Name, age and gender;

Related to the patient: Diagnosis, ASA classification assessed by the anesthesiologist and defined as: Class I - normal healthy patients; Class II - patients with mild systemic disease; Class III - patients with severe systemic disease; Class IV - patients with severe systemic disease that is a constant threat to life; and Class $\mathrm{V}$ - a moribund patients who is not expected to survive without the operation ${ }^{(12)}$.

Charlson index (severity of the clinical picture): assessed by the researchers, it interprets the gravity by the accumulation of diagnosed diseases (comorbidities). The result is obtained by adding the points attributed to each of the diagnoses. Although it was designed to assess the risk of death in chronic diseases ${ }^{(13)}$, the Charlson index was appropriate to estimate the combined impact of comorbidities on the risk of acquiring nosocomial acute infections ${ }^{(14)}$. Moreover, it is easily calculated from data collected retrospectively from medical records.

Diabetes mellitus is characterized by fasting blood glucose greater than $126 \mathrm{mg} / \mathrm{dl}$ or history of treatment with oral hypoglycemics and/or insulin.

The body mass index (BMI), calculated with the weight and height measurements according to the following formula BMI = weight $(\mathrm{kg}) /$ height $^{2}(\mathrm{~cm})$ and classified as: low weight (BMI < 18.5); normal weight (BMI 18.5-24.99); overweight (BMI 25-29.99) and obesity (BMI $\geq 30.00$ ).

History of alcohol consumption characterized by information obtained in the first interview and classified as yes and no. Smoking habits characterized by information obtained in the first interview and classified as yes and no. Use of immunosuppressive drugs classified as yes and no. Chemotherapy and/or radiotherapy prior to surgery. Preexisting infection before the surgery. Glucose level in the perioperative period.

Related to the surgical procedure: pre and post-surgical hospitalization days. Mechanical bowel preparation: defined as a particular oral preparation or the rectal enema procedure before surgery to clean the fecal matter from intestinal lumen. Antibiotic prophylaxis classified as yes and no, drug used and time of use. Surgical time in minutes.

Potential of contamination, classified as ${ }^{(15)}$ : potentially contaminated: those carried out in tissues contaminated with small quantity of microbial flora or in tissues of difficult decontamination, in the absence of infectious and inflammatory process, and with discrete technical problems during surgery.

Contaminated: those made in recently traumatized and open tissues colonized by abundant bacterial flora, with difficult or impossible decontamination, and all those in which there were gross technical failures, and absence of local suppuration. 
Infected: all surgeries performed in any tissue or organ in the presence of infectious process (local suppuration) and/ or necrotic tissue ${ }^{(15)}$. Red blood cell transfusion in the perioperative period. Use of devices in the perioperative period: indwelling urinary catheter, nasogastric tube and/or nasoenteral tube. Allocation and type of abdominal drains in the perioperative period. Ostomy procedures in the perioperative period. SSI: date of diagnosis, microbial etiology. Patient evolution: hospital discharge or death.

The information was stored in an Excel database (CMicrosoft, Redmond, WA, USA) and analyzed using the Statistical Package for the Social Sciences for Windows, version 19.0 (C) IBM, Armonk, NY, USA).

First, the sample characterization was performed using absolute and relative frequencies, measures of central tendency (mean and median) and dispersion (quartiles).

For the quantitative variables was verified adherence to the normal curve using the Kolmogorov-Smirnov test. For the variables without normality was applied the nonparametric Mann-Whitney test between groups with and without SSI. The Chi-square test was used to verify the association of independent qualitative variables with the presence of infection. When this test could not be used due to the insufficient number of individuals, the Fisher's exact test was chosen.

The multivariate analysis was performed using logistic regression models. For variable selection was used the stepwise backward method. Briefly, the first model included all variables, and it was progressively reduced according to parameters of $\mathrm{p}<0.05$ for inclusion and $\mathrm{p}<0.1$ for permanence ${ }^{(16)}$. The significance parameter in the final model was $p<0.05$. As counter-evidence, we used the stepwise forward procedure, in which the variables were included one by one according to the same parameters (inclusion: $\mathrm{p}<0.05$; permanence: $\mathrm{p}<0.1$ ). The results were similar in both strategies.

The study was approved by the Research Ethics Committee of the Faculdade de Medicina de Botucatu - UNESP, through the Plataforma Brasil program under number 607.277, of 07/04/2014 (CAAE: 28966314.0.0000.5411).

\section{RESULTS}

From January 2010 until December 2013 were performed 178 colon surgeries and all patients were followed from the time of admission until discharge. They received phone calls from the CCIRAS of the hospital 30 days after the date of surgery, except for those who died during the hospitalization period. We excluded 23 patients whose medical records were not available for consultation during the study period, representing $12.9 \%$ of loss. Therefore, the sample consisted of 155 patients.

In relation to the demographic characteristics of participants, the female gender predominated (52.25\%). The age range was 20-95 years, mean of 59.3 years and $50 \%$ of individuals were aged below 61 years.

Cancer of the colon and rectum were the most prevalent pathologies, followed by acute abdomen and intestinal subocclusion, among others. The preoperative BMI of patients was found only in 92 medical records, and obesity was pres- ent in 10 cases (10.8\%). The Charlson index was used to estimate the severity of patients' clinical picture, and it was higher in those who had SSI. The ASA classification given by anesthesiologists showed that $77.4 \%$ of patients had mild or severe systemic disease (ASA II and III).

Of all analyzed surgeries, 33 were performed in 2010 , 53 in 2011, 38 in 2012 and 31 in 2013. According to the potential for contamination, they were distributed in potentially contaminated (75.4\%), contaminated (16.7\%) and infected (5.1\%). Regarding the incidence of SSI in the studied period, 11 cases were diagnosed during hospitalization (7\% rate), and 15 cases during post-discharge surveillance $(9.7 \%$ rate), divided by the year of incidence, as shown in figure 1 . Note that in $2010,100 \%$ of cases were identified by postdischarge surveillance. Thus, by performing post-discharge surveillance, the overall rate found was $16.7 \%$ of SSI. It was not possible to identify the microbial etiology of SSI given the non-systematic collection of material for culture.

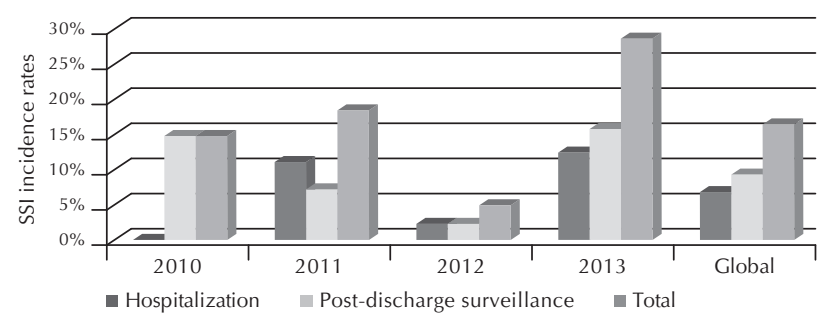

Figure 1 - Distribution of incidence rates of SSI in patients undergoing colon surgery during hospitalization and after discharge, according to the year of occurrence, HC-FMB - Botucatu, SP, Brazil, 2010-2013.

Antibiotic prophylaxis was performed in 137 patients (88.4\%) and the most prevalent prescribed drugs were cefoxitin (second-generation cephalosporin) in 54.0\% of cases, followed by cefazolin (first-generation cephalosporin) with $24.8 \%$, and ciprofloxacin (second-generation quinolone) associated with metronidazole in $16.8 \%$. The mean duration of use was 2.5 days.

Mechanical bowel preparation was performed in $51.6 \%$ of patients, with incidence increased to $88.5 \%$ in patients who developed SSI. The main therapeutic indicated was enteroclysis (66.2\%), followed by glycerol (47.5\%), bisacodyl (33.7\%), mineral oil (30\%) and magnesium hydroxide (18.7\%). Note that $68.7 \%$ of patients used only a therapeutic method and $31.3 \%$ used two or more therapies associated.

In the perioperative period, transfusion of blood products was indicated for $58 \%$ of patients. Drains allocation during surgery occurred in $44.5 \%$ patients. The open drainage (Penrose drains) was the most used drainage type, in $89.9 \%$ of cases versus $10.1 \%$ of closed drainage (portovac drain). Ostomies were performed in $25.8 \%$ of procedures.

The perioperative glycemic control is not routinely performed in this service and data on hair removal and skin antisepsis were not found in the medical records, making the collection impossible.

A statistically significant association was found both in the univariate and in the multivariate analysis between the SSI and the following variables: male gender, Charlson index, and mechanical bowel preparation (Table 1). 
Table 1 - Risk factors for acquiring SSI in colon surgery (univariate and multivariate analysis, HC-FMB - Botucatu, SP, Brazil, $2010-2013$.

\begin{tabular}{|c|c|c|c|c|c|c|}
\hline \multirow{2}{*}{ Risk factor } & \multicolumn{4}{|c|}{ Univariate analysis } & \multicolumn{2}{|c|}{ Multivariate analysis } \\
\hline & SSI (26) & No SSI (129) & OR $(\mathrm{Cl} 95 \%)$ & $\mathbf{p}$ & OR $(\mathrm{Cl95} \%)$ & $\mathbf{p}$ \\
\hline \multicolumn{7}{|l|}{ Demographic data } \\
\hline Age (median, quartiles) & $63(45-74)$ & $60(51-70)$ & $\ldots$ & 0.9 & & \\
\hline Male & $19(73.1)$ & 55 (42.6) & $3.65(1.44-9.30)$ & 0.005 & $3.53(1.33-9.35)$ & 0.01 \\
\hline \multicolumn{7}{|l|}{ Related to the patient } \\
\hline Alcoholism & $1(3.8)$ & $12(9.3)$ & $0.39(0.05-3.14)$ & 0.7 & & \\
\hline Smoking habits & $3(11.5)$ & $11(8.5)$ & $1.40(0.36-5.41)$ & 0.7 & & \\
\hline Chemotherapy & $1(3.8)$ & $5(3.9)$ & $0.00(0.11-8.86)$ & 1 & & \\
\hline Radiotherapy & $0(0)$ & $2(1.6)$ & $\cdots$ & 1 & & \\
\hline ASA (median, quartiles) & $2(2-3)$ & $2(2-2)$ & $\ldots$ & 0.2 & & \\
\hline Charlson index (median, quartiles) & $3(1-3)$ & $2(0-2)$ & ... & 0.002 & $1.66(1.12-2.44)$ & 0.01 \\
\hline Preoperative infection & $0(0)$ & $2(1.6)$ & $\cdots$ & 1 & & \\
\hline \multicolumn{7}{|l|}{ Related to the surgical procedure } \\
\hline $\begin{array}{l}\text { Preoperative hospitalization days (median, } \\
\text { quartiles) }\end{array}$ & $2(2-6)$ & $4(1-8)$ & $\cdots$ & 0.6 & & \\
\hline Bowel preparation & $23(88.5)$ & $88(63.3)$ & $4.39(1.25-15.42)$ & 0.01 & $4.96(1.33-18.54)$ & 0.02 \\
\hline Antibiotic prophylaxis & $24(92.3)$ & $113(87.6)$ & $1.70(0.37-7.8)$ & 0.7 & & \\
\hline Operative time (median, quartiles) & $180(120-196)$ & $180(120-240)$ & $\cdots$ & 0.7 & & \\
\hline Blood components & $16(61.5)$ & $74(57.4)$ & $1.89(0.50-2.82)$ & 0.7 & & \\
\hline IUC use & $21(80.8)$ & $101(78.3)$ & $1.16(0.40-3.30)$ & 0.8 & & \\
\hline NG use & $7(26.9)$ & $58(45.0)$ & $0.45(0.18-1.15)$ & 0.09 & & \\
\hline NE use & $0(0.0)$ & $3(2.3)$ & $\cdots$ & 1 & & \\
\hline Drains & $15(57.5)$ & $54(41.9)$ & $1.89(0.81-4.45)$ & 0.13 & & \\
\hline Ostomy & $7(26.9)$ & $33(25.6)$ & $1.07(0.41-2.78)$ & 0.9 & & \\
\hline
\end{tabular}

Note: All results in figures (\%) unless otherwise specified. SSI = surgical site infection. OR= Odds ratio. CI = Confidence interval. ASA= American Society of Anesthesiology. $\mathrm{IUC}=$ Indwelling urinary catheter. $\mathrm{NG}=$ Nasogastric tube. $\mathrm{NE}=$ Nasoenteral tube.

The outcomes associated with SSI were length of hospitalization and death, shown in table 2. The time of postoperative hospital stay was significantly higher among those who developed SSI, compared to those who did not develop this condition $(\mathrm{p}=0.01)$.

Among the patients who underwent colon surgery, 26 died resulting in an overall mortality rate of $16.8 \%$.

Table 2 - Outcomes of patients undergoing colon surgery associated with SSI (univariate analysis), HC-FMB - Botucatu, SP, Brazil, 2010-2013.

\begin{tabular}{lcccc}
\hline \multirow{2}{*}{ Evolution } & \multicolumn{4}{c}{ Univariate analysis } \\
\cline { 2 - 5 } & SSI (26) & $\begin{array}{c}\text { Without SSI } \\
(\mathbf{1 2 9})\end{array}$ & $\begin{array}{c}\text { OR } \\
\text { (CI 95\%) }\end{array}$ & $\mathbf{p}$ \\
\hline $\begin{array}{l}\text { Total hospitalization } \\
\text { days }\end{array}$ & $14.5(10-20)$ & $12(8.5-18)$ & $\ldots$ & 0.2 \\
Postoperative days & $\mathbf{9 . 5 0 ( 8 - 1 3 )}$ & $\mathbf{8}(\mathbf{6 - 1 1})$ & $\ldots$ & $\mathbf{0 . 0 1}$ \\
Death & $5(18.5)$ & $21(16.4)$ & $\ldots$ & 0.8 \\
\hline
\end{tabular}

Note: All results in figures (\%). SSI= Surgical site infection. $\mathrm{OR}=\mathrm{Odds}$ ratio. $\mathrm{CI}=$ Confidence interval.

\section{DISCUSSION}

Of the 155 patients undergoing colon surgery, were diagnosed 11 cases of SSI during hospitalization, and 15

cases were reported with post-discharge surveillance, showing an incidence of $7 \%$ and $9.7 \%$, respectively, and the total of $16.7 \%$. The incidence rate of SSI found was consistent with the literature data ${ }^{(5-11)}$.

In a national prospective study conducted in a university hospital, of 357 patients undergoing surgery of the digestive tract, were reported 64 SSI cases, of which 16 occurred during hospitalization, and 40 after discharge, resulting in incidences of $4.5 \%$ and $13.9 \%$, respectively ${ }^{(10)}$. In another prospective study in two teaching hospitals, 501 patients underwent gastrointestinal surgery, and 140 SSI cases were diagnosed, of which, 31 reported during hospitalization and 109 during post-discharge, with incidence rates of $6.2 \%$ and $28 \%$, respectively ${ }^{(11)}$. Without completing the post-discharge follow-up, $77.9 \%$ of the SSI cases would not be notified ${ }^{(11)}$. This shows that if the post-discharge surveillance had not been performed, the overall rate of SSI would be greatly underreported.

This study showed that the risk factors for SSI related to patients were the male gender and the Charlson index. The factor related to the surgery was mechanical bowel preparation.

An American study evaluating the perioperative results in 115 patients undergoing renal laparoscopic pro- 
cedures found that patients with a Charlson comorbidity index $>2$ were more likely to acquire perioperative complications than patients with a score $<1(p=0.034)^{(17)}$. Another Spanish study followed 186 patients who underwent surgery because of acute mesenteric ischemia in a university hospital between 1990 and 2006. The Charlson index was calculated preoperatively for each patient and the perioperative mortality and overall survival were recorded. It concluded that the Charlson index may be a predictive factor of perioperative mortality and long-term survival in patients operated for acute mesenteric ischemia ${ }^{(18)}$. Thus, there is a trend in using the Charlson index not only as a predictor of mortality, but also as a predictor of postoperative complications such as the SSI, as demonstrated in the present study.

Mechanical bowel preparation was initially recommended to reduce the bacterial load in the colon and thus, reduce infections ${ }^{(19)}$. A literature review described the results of studies conducted between 2000 and 2010 on mechanical bowel preparation versus no preparation of colon and rectum in elective surgical resections in the prevention of surgical site infections. It indicated that this practice may be safely abandoned for most procedures and patients, even though many surgeons continue to use the preoperative mechanical preparation routinely ${ }^{(19)}$. Clinical trials and retrospective reviews found a trend of increased infectious complications in patients who underwent preparation, compared to those who did not ${ }^{(20-22)}$. There are also reports of early return of bowel function and shorter hospital stay among patients who did not undergo preparation before surgery ${ }^{(21-22)}$.

However, a large multicenter study and a review conducted by the Cochrane Collaboration found that there was no difference in the fistula rate or severity of infectious complications when comparing a group that used mechanical bowel preparation and another group that did not use it ${ }^{(23-24)}$.

Although several studies are favorable to the safety of colorectal procedures without mechanical bowel preparation, doctors have been cautious to abandon the practice ${ }^{(19)}$. A study involving nearly 300 hospitals in Europe and the United States found that in $96 \%$ of patients admitted for colorectal procedure the mechanical bowel preparation was used preoperatively ${ }^{(25)}$. Reports of Switzerland and New Zealand are more in line with the recommendations to abandon the practice, with less than half of doctors reporting the use of preparation in colon procedures. However, even in these countries, the use of preparation is common during anorectal surgeries (60-80\%) $)^{(26-27)}$.

In the present investigation, SSI was also associated with longer postoperative hospital stay. A study aimed to retrospectively evaluate the economic impact of nosocomial infections acquired in the ICU noted that patients with infection, especially SSI and catheter-associated bloodstream infections, presented higher costs in the $\mathrm{ICU}^{(28)}$. In addition to antimicrobials costs, other resources related to life support in these patients may account for higher expenses, implying on large economic impact of infections acquired in ICUs in hospitals of the SUS (Brazilian Unified Health system). In addition to direct expenses in health care, the increased length of stay in the ICU may have a significant impact in terms of public health, since this is a major limiting to intensive care access. National data related to expenses with materials and drugs in this patient group are scarce ${ }^{(28)}$.

Finally, there are limitations when conducting a retrospective study, since it is not always possible to recover all information from patients' medical records. The preoperative BMI of patients was found only in $59.3 \%$ of medical records, the evaluation of perioperative blood glucose is not performed routinely in service, and data on trichotomy and antisepsis of the skin were not found in the records, making the collection impossible. Twenty-three medical records were not found during the collection period, representing a loss of $12.9 \%$ of cases.

\section{CONCLUSION}

In this study, the incidence of SSI in patients undergoing colon surgery was $16.7 \%$, and of these, $9.7 \%$ were identified during post-discharge surveillance. The risk factors associated with SSI related to the patient were male gender and the Charlson index. The factor related to the surgery was the mechanical bowel preparation. SSI was also associated with longer postoperative hospital stay.

Hospital infections affect both developed and developing countries, directly altering the quality indicators of hospitals and the prognosis of patients, besides demanding higher costs for institutions and increasing the hospital stay.

As in other studies, it is key that the health professionals understand about the risk factors influencing the incidence of SSI. This way, they can contribute to new studies on the quality of care provided to surgical patients, from effective actions that minimize the risk of infections.

\section{RESUMO}

Objetivo: Identificar a ocorrência de infecção de sítio cirúrgico (ISC) e seus fatores de risco em pacientes submetidos a cirurgias de cólon, em um hospital terciário do interior paulista. Método: Estudo de coorte não concorrente, por meio do levantamento de informações contidas nos prontuários de pacientes submetidos a cirurgias de cólon no período compreendido entre janeiro de 2010 e dezembro de 2013. As variáveis estudadas foram os possíveis fatores de risco ligados ao paciente, às características demográficas e ao procedimento cirúrgico. Resultados: Foram avaliados 155 pacientes, com uma incidência global de ISC de 16,7\%. Encontrou-se associação estatisticamente significativa tanto na análise uni quanto na multivariada entre a ISC e as seguintes variáveis: sexo masculino, pontuação de Charlson e preparo mecânico intestinal. Conclusão: A compreensão dos profissionais de saúde sobre os fatores que influenciam a incidência de ISC nas cirurgias de cólon pode contribuir para a qualidade da assistência prestada ao paciente cirúrgico a partir de ações efetivas que minimizem os riscos de infecções. 
DESCRITORES

Infecção da Ferida Operatória; Cirurgia Colorretal; Enfermagem Perioperatória.

\section{RESUMEN}

Objetivo: Identificar la ocurrencia de infección de sitio quirúrgico (ISQ) y sus factores de riesgo en pacientes sometidos a cirugías de colon, en un hospital terciario del interior del Estado de São Paulo. Método: Estudio de cohorte no concurrente, mediante relevamiento de informaciones contenidas en las fichas de pacientes sometidos a cirugías de colon en el período comprendido entre enero de 2010 y diciembre de 2013. Las variables estudiadas fueron los posibles factores de riesgo vinculados con el paciente, los rasgos demográficos y el procedimiento quirúrgico. Resultados: Fueron evaluados 155 pacientes, con una incidencia global de ISQ del 16,7\%. Se encontró asociación estadísticamente significativa tanto en el análisis univariado como en el multivariado entre la ISQ y las siguientes variables: sexo masculino, puntuación de Charlson y preparación mecánica intestinal. Conclusión: La comprensión de los profesionales de la salud acerca de los factores que influencian la incidencia de ISQ en las cirugías de colon puede contribuir a la calidad de la asistencia prestada al paciente quirúrgico mediante acciones efectivas que minimicen los riesgos de infecciones.

\section{DESCRIPTORES}

Infección de Herida Operatoria; Cirugía Colorrectal; Enfermería Perioperatoria.

\section{REFERENCES}

1. Magill SS, Hellinger W, Cohen J, Kay R, Bailey C, Boland B, et al. Prevalence of healthcare-associated infections in acute care hospitals in Jacksonville, Florida. Infect Control Hosp Epidemiol. 2012;33(3):283-91.

2. Centers for Disease Control and Prevention; The National Healthcare Safety Network. Surgical Site Infection (SSI) Event. Manual: patient safety component manual [Internet]. Atlanta: CDC; 2015 [cited 2015 Feb 16]. Available from: http://www.cdc.gov/nhsn/PDFs/ pscManual/9pscSSlcurrent.pdf

3. Brasil. Ministério da Saúde; Agência Nacional de Vigilância Sanitária. Critérios nacionais de infecções relacionadas à assistência [Internet]. Brasília; 2009 [citado 2015 jan. 20]. Disponível em: http://www.anvisa.gov.br/servicosaude/manuais/criterios_nacionais_ISC.pdf

4. Lissovoy G, Fraeman K, Hutchins V, Murphy D, Song D, Vaughn BB. Surgical site infection: incidence and impact on hospital utilization and treatment costs. Am J Infect Control. 2009;37(5):387-97.

5. Manilich E, Vogel JD, Kiran RP, Church JM, Seyidova-Khoshknabi D, Remzi FH. Key factors associated with postoperative complications in patients undergoing colorectal surgery. Dis Colon Rectum. 2013;56(1):64-71.

6. Hedrick TL, Sawyer RG, Friel CM, Stukenborg GJ. A method for estimating the risk of surgical site infection in patients with abdominal colorectal procedures. Dis Colon Rectum. 2013;56(5):627-37.

7. Gervaz P, Bandiera-Clerc C, Buchs NC, Eisenring MC, Troillet N, Perneger T, et al. Scoring system to predict the risk of surgical-site infection after colorectal resection. Br J Surg. 2012;99(4):589-95.

8. Kurmann A, Vorburger SA, Candinas D, Beldi G. Operation time and body mass index are significant risk factors for surgical site infection in laparoscopic sigmoid resection: a multicenter study. Surg Endosc. 2011;25(11):3531-4.

9. Amri R, Bordeianou LG, Sylla P, Berger DL. Obesity, outcomes and quality of care: body mass index increases the risk of wound-related complications in colon cancer surgery. Am J Surg. 2014;207(1):17-23.

10. Oliveira AC, Ciosak SI. Infecção de sítio cirúrgico em hospital universitário: vigilância pós-alta e fatores de risco. Rev Esc Enferm USP. 2007;41(2):258-63.

11. Oliveira AC, Ciosak SI. Infecção de sítio cirúrgico no seguimento pós-alta: impacto na incidência e avaliação dos métodos utilizados. Rev Esc Enferm USP. 2004;38(4):379-85.

12. Dripps RD. New classification of physical status. Anesthesiology. 1963;24:111.

13. Charlson ME, Pompei P, Ales KL, MacKenzie CR. A new method classifying prognostic comorbidity in longitudinal studies: development and validation. J Chronic Dis. 1987; 40(5):373-83.

14. Fortaleza CMCB, Freitas FM, Lauterbach GP. Colonization pressure and risk factors for acquisition of imipenem-resistant Acinetobacter baumannii in a medical surgical intensive care unit in Brazil. Am J Infect Control. 2013;41(3):263-5.

15. Brasil. Ministério da Saúde. Portaria n. 2616, de 12 de maio de 1998. Dispõe sobre normas destinadas ao controle de infecções hospitalares [Internet]. Brasília; 1998 [citado 2014 dez. 8]. Disponível em: http://www.saude.mg.gov.br/images/documentos/portaria_2616.pdf

16. Greenland S. Modeling and variable selection in epidemiologic analysis. Am J Public Health. 1989;79(3):340-9.

17. Guzzo TJ, Allaf ME, Pierorazio PM, Miller D, McNeil BK, Kavoussi LR, et al. Perioperative outcomes of elderly patients undergoing laparoscopic renal procedures. Urology. 2009;73(3):572-6.

18. Marchena-Gomez J, Acosta-Merida MA, Hemmersbach-Miller M, Conde-Martel A, Roque-Castellano C, Hernandez-Romero J. The ageadjusted Charlson comorbidity index as an outcome predictor of patients with acute mesenteric ischemia. Ann Vasc Surg. 2009;23(4):458-64.

19. Kumar AS, Kelleher DC, Sigle GW. Preparation before elective surgery. Clin Colon Retal Surg. 2013;26(3):146-52.

20. Bucher P, Gervaz P, Soravia C, Mermillod B, Erne M, Morel P. Randomized clinical trial of mechanical bowel preparation versus no preparation before elective left-sided colorectal surgery. Br J Surg. 2005;92(4):409-14.

21. Howard DD, White CQ, Harden TR, Ellis CN. Incidence of surgical site infections postcolorectal resections without preoperative mechanical or antibiotic bowel preparation Am Surg. 2009;75(8):259-63.

22. Bretagnol F, Alves A, Ricci A, Valleur P, Panis Y. Rectal cancer surgery without mechanical bowel preparation. Br J Surg. 2007;94(10):1266-71. 
23. Jung B, Pahlman L, Nystrom PO, Nilsson E. Mechanical Bowel Preparation Study Group. Multicentre randomized clinical trial of mechanical bowel preparation in elective colonic resection. Br J Surg. 2007;94(6):689-95.

24. Güenaga KF, Matos D, Wille-Jorgensen P. Mechanical bowel preparation for elective colorectal surgery. Cochrane Database Syst Rev. 2011;(9):CD001544.

25. Kehlet H, Büchler MW, Beart RW Jr, Billingham RP, Williamson R. Care after colonic operation - is it evidence-based? Results from a multinational survey in Europe and the United States. J Am Coll Surg. 2006;202(1):45-54.

26. Businger A, Grunder G, Guenin MO, Ackermann C, Peterli R, von Flüe M. Mechanical bowel preparation and antimicrobial prophylaxis in elective colorectal surgery in Switzerland - a survey. Langenbecks Arch Surg. 2011;396(1):107-13.

27. Kahokehr A, Robertson P, Sammour T, Soop M, Hill AG. Perioperative care: a survey of New Zealand and Australian colorectal surgeons. Colorectal Dis. 2011;13(11):1308-13.

28. Nangino GO, Oliveira CD, Correia PC, Machado NM, Dias ATB. Impacto financeiro das infecções nosocomiais em unidades de terapia intensiva em hospital filantrópico de Minas Gerais. Rev Bras Ter Intensive. 2012;24(4):357-61. 